Article

\title{
Screening of cyanide-utilizing bacteria from rumen and in vitro evaluation of fresh cassava root utilization with pellet containing high sulfur diet
}

\author{
Rittikeard Prachumchai ${ }^{1}$, Anusorn Cherdthong ${ }^{1^{*}}$, and Metha Wanapat ${ }^{1}$ \\ ${ }^{1}$ Tropical Feed Resources Research and Development Center (TROFREC), Department of Animal Science, \\ Faculty of Agriculture, Khon Kaen University, Khon Kaen 40002, Thailand. \\ * Correspondence: anusornc@kku.ac.th; Tel: +66-43-202362
}

\begin{abstract}
Two experiments were undertaken to screen the ruminal cyanide-utilizing bacteria (Experiment 1), and to evaluate the influence of fresh cassava root (FCR) and pellets containing high sulfur (PELFUR) on cyanide content, kinetics of gas, in vitro degradability, and ruminal fermentation (Experiment 2). Experiment 1 was conducted in a completely randomized design (CRD) for a screening of cyanide-utilizing bacteria and the dietary treatments were the level of cyanide at $0,150,300$, and $450 \mathrm{ppm}$. In experiment 2, a $5 \times 3$ factorial arrangement in a completely randomized design was used for in vitro study. Factor A was the level of FCR at 0, 260, 350, 440, and $530 \mathrm{~g} / \mathrm{kg}$ of dry matter (DM) substrate, and factor B was the level of PELFUR at 0,15 , and $30 \mathrm{~g} / \mathrm{kg}$ DM substrate. Experiment 1, adding different doses of cyanide significantly affected cyanideutilizing rumen bacterial growth ( $\mathrm{p}<0.05)$. Increasing the concentration of cyanide from 0 to 150 and 150 to $300 \mathrm{ppm}$, resulted in an increase in cyanide-utilizing rumen bacteria of $38.2 \%$ and $15.0 \%$, respectively. Experiment 2, no interaction effects were found between FCR and PELFUR doses on kinetics of gas ( $p>0.05)$. Increasing the FCR level to more than $260 \mathrm{~g} / \mathrm{kg}$ of DM substrate could increase cumulative gas production ( $p<0.05)$. Increasing doses of PELFUR from 15 to $30 \mathrm{~g} / \mathrm{kg}$ increased the cumulative gas production when compared with that of $0 \mathrm{~g}$ PELFUR $/ \mathrm{kg}$ of DM substrate $(p<0.05)$. Cyanide concentration in rumen fluid decreased with PELFUR $(p<0.05)$ supplementation. Degradability of in vitro DM and organic matter following incubation increased at 12 and $24 \mathrm{~h}$ due to PELFUR supplementation with FCR and increased additionally with $15 \mathrm{~g}$ PELFUR/kg of DM substrate $(\mathrm{p}<0.05)$ in $440 \mathrm{~g}$ FCR/kg of DM substrate. Proportions of the total volatile fatty acids, acetic acid (C2), propionic acid (C3), and butyric acid among supplementations with FCR $(\mathrm{p}<0.05)$ were significantly different. In conclusion, present result is the first finding of bacteria in the rumen capable of utilizing cyanide, and cyanide might function as a nitrogen source for bacterial cell synthesis. Inclusion of FCR of $530 \mathrm{~g} / \mathrm{kg}$ with $30 \mathrm{~g}$ PELFUR/kg of DM substrate could increase the cumulative gas production, the bacterial population, the in vitro degradability, the proportion of $\mathrm{C} 3$, and the rate of the disappearance of cyanide.
\end{abstract}

Keywords: Thiocyanate; Cyanide-utilizing bacteria; Rumen fermentation; Cyanide; degradability

\section{Introduction}

An energy source, cassava root, is used for animal diets, especially in the tropical region [1]. It can be used for human food and as an energy ingredient in animal diets. Normally, cassava root is sliced and sun-dried, called cassava chip, prior to using as an ingredient in animal diets. The dried form of cassava root has been reported to have high degradability in the rumen (95-99\%) [2]. Feeding cassava roots as a fresh form to ruminants is more feasible in all seasons [3]. Cherdthong et al. [2] stated that feeding fresh cassava root (FCR) could be another way to increase the use of cassava roots without prior to processing. However, cyanogenic compounds contained in cassava roots including linamarin and lotaustralin, are constraints for FCR usage. The compounds, cyanohydrins, produced 
via a hydrolysis process, starting with linamarin as a precursor to linamarase whilst more hydrolysis there is, the more toxic the root could be [4].

Cyanide poisoning is related to the amount of feed consumed and the animal's physiological condition, and a cyanide level exceeding $200 \mathrm{mg} / \mathrm{kg}$ on a wet weight basis is dangerous. On a dry matter basis, feeds with more than $500 \mathrm{mg}$ cyanide/kg should be considered potentially toxic [5]. Cherdthong et al. [2] demonstrated that an average cyanide content of 85 to $114 \mathrm{mg} / \mathrm{kg}$ fresh matter (FM) basis is contained in FCR. Promkot and Wanapat [6] suggested that microbes in the rumen could be able to eliminate the negative effects of cyanide. Similarly, Jones and Megarrity [7] demonstrated that leucaena toxicity (mimosine) can be degraded by rumen microbe namely Synergistes jonesii. However, no previous report elucidated whether the rumen microbes could degrade cyanide. Two enzymes are of particular interest in the rumen microbes such as rhodanase and mercaptopyruvatesulfurtransferase. Rhodanese is a mitochondrial enzyme that functions to detoxify cyanide into thiocyanate, which is safe, then excrete out of the ruminant via urine [8]. The conversion of thiocyanate from cyanide via rhodanese involves a cofactor, called sulfane-sulfur. This cofactor's availability is relies on the availability of amino acid having sulfur in the structure. In the diets containing low amounts of these amino acids, addition of sulfur is suggested [9]. Cherdthong et al. [2] found that supplementation of FCR at $10 \mathrm{~g} / \mathrm{kg}$ and $15 \mathrm{~g} / \mathrm{kg}$ of BW with feed blocks containing sulfur at 20 and $40 \mathrm{~g} / \mathrm{kg}$ did not have a negative effect on digestibility and rumen fermentation, and cyanide from FCR can be changed to thiocyanate, which is less toxic to animals. Additionally, Supapong et al. [10] suggested that $20 \mathrm{~g}$ sulfur $/ \mathrm{kg}$ supplementation in fermented total mixed ration (FTMR) containing FCR and fermented for 7 days improved digestibility of nutrients, microbial protein synthesis effectiveness, and total volatile fatty acids (VFAs), propionic acid, and thiocyanate in blood. However, feeding animals with feed products such as sulfur-containing pellets requires, in particular, an increase in value-added feed and a convenient practical use for farmers.

Pelleted feeds have been successfully used for animals. Pelleting improves the palatability, density, and quality of feedstuff [11]. Pellet diets could enhance nutrient digestibility and fermentation in the rumen $[12,13]$. According to our review, a study on the influence of FCR and pellets containing sulfur on the change of ruminal fermentation has not yet been conducted. It was hypothesized that FCR and pellets containing sulfur could reduce cyanide content and enhance ruminal fermentation, mainly propionic acid production.

Therefore, the current work aimed to screen the ruminal cyanide-utilizing bacteria and evaluate the influence of FCR and pellets containing high sulfur (PELFUR) diet on cyanide content, kinetics of gas, in vitro degradability, and ruminal fermentation.

\section{Materials and methods}

The approval protocol no. ACUC-KKU 11/2563 was issued by the Animal Welfare Committees of Khon Kaen University.

\subsection{Screening of cyanide-utilizing bacteria in the rumen}

\subsubsection{Animals and feeding}

Two donors, fistulated dairy cows $370 \pm 10 \mathrm{~kg}$ in weight, were used. Cows were offered a concentrate, composed of $140 \mathrm{~g} / \mathrm{kg}$ DM crude protein (CP), $410 \mathrm{~g} / \mathrm{kg}$ DM ether extract (EE), $220 \mathrm{~g} / \mathrm{kg}$ $\mathrm{DM}$ neutral detergent fiber (NDF), $110 \mathrm{~g} / \mathrm{kg}$ DM acid detergent fiber (ADF), and total digestible nutrient of $756 \mathrm{~g} / \mathrm{kg}$ DM. Cows were fed at $5 \mathrm{~g} / \mathrm{kg}$ of their weight daily for 21 days at 7:00 and 15:30 and rice straw was fed on ad libitum basis. Free water and a mineral-block were provided for each cow housed individually. The rumen fluid $(100 \mathrm{ml})$ was obtained from each cow before morning feeding, and then was filtered through layers of cheesecloth into warmed thermos bottles $\left(39^{\circ} \mathrm{C}\right)$ and transported to the laboratory using a sealed thermos under continuous flushing with carbon dioxide.

2.1.2. Sampling and enrichment culture for cyanide-utilizing bacteria in rumen 
After obtaining inoculum, a 500-ml Erlenmeyer flask was filled with $90 \mathrm{ml}$ of saline solution with $1 \mathrm{~g} / 1$ Tween 80 . The solution made moving microorganisms from rumen fluid to the aqueous phase easier. Then, the saline solution was added to $10 \mathrm{ml}$ of rumen fluid and mixed at $39{ }^{\circ} \mathrm{C}$ and $150 \mathrm{rpm}$ for $1 \mathrm{~h}$. The enrichment of the microorganism was done in a fresh medium by $100 \mathrm{~g} / \mathrm{v} / \mathrm{v}$ inoculation every 4 days. Following three successive subcultures as above, $0.1 \mathrm{ml}$ crop aliquots were streaked on nutrient agar plates with a nitrogen source of $1 \mathrm{mM}$ cyanide. Nutrient agar plates were distilled for the isolation of colonies at $4{ }^{\circ} \mathrm{C}$. The $\mathrm{pH}(6.5-7.0)$ was maintained with $0.1 \mathrm{NaOH} ; 10 \mathrm{ml}$ or $100 \mathrm{~g} / \mathrm{l}$ of cultured $\mathrm{H}_{2} \mathrm{SO}_{4}$ was added to the flask to test for cyanide-utilizing bacteria [14].

\subsubsection{Media and culture conditions}

According to Kandasamy et al. [14] who suggested that $\mathrm{NaCN}$ can be used as a sole nitrogen source for cyanide utilizing bacteria in cassava factory wastewater. A mineral medium containing 10 $\mathrm{g} / \mathrm{l}(\mathrm{w} / \mathrm{v}) \mathrm{NaCN}$ and $10 \mathrm{~g} / \mathrm{l}(\mathrm{w} / \mathrm{v})$ glucose was the enrichment material. The mineral medium was composed of $0.1 \mathrm{M} \mathrm{NaOH}, 4.35 \mathrm{~g} / 1 \mathrm{~K}_{2} \mathrm{HPO}_{4}$, and $10 \mathrm{ml}$ of a salt mixture containing $300 \mathrm{mg}$ of ferrous sulfate heptahydrate, $180 \mathrm{mg}$ of magnesium sulphate heptahydrate, $130 \mathrm{mg}$ cobalt (II) chloride, 40 mg calcium chloride, $40 \mathrm{mg}$ manganese (II) chloride tetrahydrate, and $20 \mathrm{mg}$ molybdenum (VI) oxide in 11 deionized water. The $\mathrm{pH}$ was balanced within a 6.5-7 range. The medium was sterilized by autoclave at $15 \mathrm{psi}$ and $121^{\circ} \mathrm{C}$ for $20 \mathrm{~min}$. The experiment was conducted in a completely randomized design. Dietary treatments were the level of cyanide at $0,150,300$, and 450 ppm. Cyanide as the $\mathrm{NaCN}$ solution $(1 \mathrm{~g} / \mathrm{l})$ and glucose $(1 \mathrm{~g} / \mathrm{l})$ were filter-sterilized before adding into the samples. $(0.2 \mathrm{ml}$ pore size; Advantec Toyo Kaisha, Ltd., Tokyo, Japan). The NaCN was inserted via a silicone septum into the culture using a syringe [15].

\subsubsection{Bacterial growth}

Microorganisms were counted using the plate counting method [16] and recorded as cfu/g fresh matter (FM). Ten grams of FM in $10^{-1}$ to $10^{-5}$ sodium chloride solution were applied to $90 \mathrm{~mL}$ of sterilized distilled water, shaken well by hand, and serially diluted by $8.5 \mathrm{~g} / \mathrm{l}$. For each dilution, $20 \mu \mathrm{l}$ were placed on agar plates. In anaerobic conditions (Sugiyama-gen Co., Ltd., Tokyo, Japan), the cyanide-utilizing rumen bacteria were counted on agar media is composed peptone $(0.5 \mathrm{~g})$, beef extract $(0.3 \mathrm{~g})$, sodium chloride $(0.8 \mathrm{~g})$, and Agar (15.0 g) after an incubation for $96 \mathrm{~h}$ at $39^{\circ} \mathrm{C}$.

\subsection{In vitro study}

\subsubsection{Pellets containing high sulfur (PELFUR) preparation and experimental design}

Feedstuffs were milled through a $0.1-\mathrm{mm}$ screen before being used as a substrate. Instead, all the ingredients were blended together well. The blended ingredients were pelleted and sun-dried for about 3 days to ensure suitable moisture content [12]. The fresh cassava root (FCR), Kasetsart 50 variety, was purchased from a local producer in Khon Kaen, Thailand. The age of harvesting FCR was 1 year, and they were washed, to 1 chopped and checked immediately.

The work was conducted in a $5 \times 3$ factorial arrangement in a completely randomized design (CRD). Factor A was the level of FCR at $0,260,350,440$, and $530 \mathrm{~g} / \mathrm{kg}$ of dry matter (DM) substrate, and factor $B$ was the level of PELFUR at 0,15 , and $30 \mathrm{~g} / \mathrm{kg}$ of DM substrate. The $0.5 \mathrm{~g}$ substrate contained a roughage-to-PELFUR ratio of 70:30, and the roughage diet was rice straw. The PELFUR, rice straw, and FCR samples were ground to pass through a 1-mm screen and perform the analysis of nutrient composition including CP, DM, and ash content [17]. Van Soest et al. [18] method was followed to analyze the content of ADF and NDF. Based on spectrophotometry, the content of cyanide in FCR was analyzed by Bradbury et al. [19] procedure and the obtained absorbance values were multiplied by the coefficient value of 396, expressed as $\mathrm{mg} / \mathrm{kg}$. Table 1 indicates the ingredients and nutrients of the PELFUR, rice straw, and FCR. 
Table 1. Ingredient and chemical composition of pellet containing high sulfur (PELFUR) in the experiment (g/kg dry matter, DM).

\begin{tabular}{lccccc}
\hline Item & PELFUR 0 & PELFUR 15 & PELFUR 30 & FCR & Rice straw \\
\hline Ingredients, g/kg DM & & & & & \\
Cassava chips & 556 & 556 & 556 & - & \\
Soybean meal & 110 & 110 & 110 & - & \\
Rice bran & 110 & 100 & 105 & - & \\
Coconut meal & 89 & 89 & 70 & - & \\
Palm kernel meal & 78 & 73 & 72 & - & \\
Urea & 10 & 10 & 10 & - & \\
Salt & 10 & 10 & 10 & - & \\
sulfur powder & 0 & 15 & 30 & - & \\
Mineral premix & 10 & 10 & 10 & - & \\
Molasses, liquid & 27 & 27 & 27 & - & \\
Chemical composition & & & & & \\
DM, g/kg as basis & 946 & 943 & 941 & 351 & 925 \\
Organic matter, g/kg DM & 925 & 921 & 932 & 924 & 895 \\
Ash, g/kg DM & 75 & 79 & 68 & 76 & 105 \\
Crude protein, g/kg DM & 132 & 130 & 130 & 21 & 23 \\
Neutral detergent fiber, g/kg DM & 228 & 231 & 226 & 156 & 712 \\
Acid detergent fiber, g/kg DM & 104 & 106 & 104 & 89 & 442 \\
Cyanide, ppm & - & - & - & 106 & - \\
\hline
\end{tabular}

$\mathrm{FCR}=$ fresh cassava root, $\mathrm{PELFUR}=$ pellet containing high sulfur

\subsubsection{Inoculum}

Two donors, fistulated dairy cow with $370 \pm 10 \mathrm{~kg}$ in weight, were used. Cows were offered a concentrate, composed of $140 \mathrm{~g} / \mathrm{kg} \mathrm{CP}, 410 \mathrm{~g} / \mathrm{kg}$ DM EE, $220 \mathrm{~g} / \mathrm{kg}$ DM NDF, $110 \mathrm{~g} / \mathrm{kg}$ DM ADF, and total digestible nutrient of $756 \mathrm{~g} / \mathrm{kg}$. Cows were fed $5 \mathrm{~g} / \mathrm{kg}$ of their weight daily for 21 days at 7:00 and 15:30 hour. Free of water and mineral-block was equipped for each cow housed individually. Before morning feeding, $3500 \mathrm{ml}$ of ruminal fluid were collected from animals and then filtered through layers of cheesecloth into warmed thermos bottles and transported to the laboratory using a sealed thermos under continuous flushing with carbon dioxide.

\subsubsection{Substrate}

Three hundred and fifty milligrams of rice straw and $150 \mathrm{mg}$ of PELFUR (70:30, rice straw-toPELFUR ratio) were weighed and added to $50-\mathrm{ml}$ glass bottles, then FCR was added at respective levels on DM basis of $0,131,175,219$, and $262 \mathrm{mg}$ DM. The dietary treatments were tested in triplicate within the incubation, and incubations were repeated on three separate days (runs). Three blanks (no substrate) were always included with each run. Menke and Steingass [20] procedure was used for the preparation of artificial saliva. A ratio of $2 \mathrm{ml}$ rumen fluid and $1 \mathrm{ml}$ artificial saliva was mixed, and incubated under the temperature of $39^{\circ} \mathrm{C}$ and continuously flushed with carbon dioxide. Then, a 40$\mathrm{ml}$ inoculum mixture was injected into the bottles, closed using stoppers made of rubber and caps made of aluminum, and warmed under $39^{\circ} \mathrm{C}$ temperature. During the incubation, the gas production was collected at $0,1,2,4,6,8,10,12,18,24,48,72$, and $96 \mathrm{~h}$.

\subsubsection{Analysis of samples}

An incubation series as described in the procedure of Ørskov and McDonald [21] was performed for the recording of produced gas, and the data of produced gas were loaded in the equation $Y=a+$ $\mathrm{b}\left[1-\mathrm{e}^{(-\mathrm{ct})}\right]$, where $\mathrm{a}$ is the produced gas from a highly degradable fraction, $\mathrm{b}$ is the produced gas from 
a slowly degradable fraction, $\mathrm{c}$ is the constant rate of produced gas from a slowly degradable fraction (b), $t$ is the time, $a+b$ is the potential extent of produced gas, and $\mathrm{Y}$ is the gas formed at $\mathrm{t}$.

Incubation times of 2 and $4 \mathrm{~h}$ were used to measure the $\mathrm{pH}$ for each bottle. After measuring $\mathrm{pH}$, $18 \mathrm{ml}$ of inoculum was taken and kept in $2 \mathrm{ml} \mathrm{H}_{2} \mathrm{SO}_{4}$ for later analyzing the content of $\mathrm{NH}_{3}-\mathrm{N}$ and VFAs. The Kjeldahl procedure [17] was performed for analyzing the content of $\mathrm{NH}_{3}-\mathrm{N}$, and Samuel et al. [22] procedure was used for analyzing the molar contents of VFAs including acetate (C2), propionate (C3), and butyrate (C4) with high-performance liquid chromatography (column Novapak C18, size $4 \times 150 \mathrm{~mm}$, Waters Corporation, Milford, MA, USA). The total VFAs was the sum of the molar contents of VFAs. Another $1 \mathrm{ml}$ of inoculum and $6 \mathrm{ml}$ of formalin were mixed to count the number of protozoal and bacterial [23]. Spectrophotometry was used to measure the cyanide concentration in the fermentation liquor [24].

Incubation times of 12 and $24 \mathrm{~h}$ were selected for the study on degradability. A sample from each replication of each treatment was transferred into a gooch crucible (40 $\mathrm{mm}$ void fraction), and the weight was recorded. The residues in each bottle were washed with distilled water. The crucibles were then oven dried to measure the DM content. The data of DM content were subtracted from the DM content in blanks, and the $\mathrm{g} / \mathrm{kg}$ of DM degradability (IVDMD) was calculated. After that, the crucibles were heated at $550{ }^{\circ} \mathrm{C}$ for 6 hours. The ash data were used to calculate the organic matter (OM) content and $\mathrm{g} / \mathrm{kg}$ of OM degradability (IVOMD) [25].

\subsection{Statistical analysis}

Cyanide-utilizing bacteria data were analyzed using the PROC GLM of SAS [26] in a completely randomized design. The model is:

$$
Y_{\mathrm{ij}}=\mu+A_{\mathrm{i}}+\varepsilon_{\mathrm{ij}}
$$

Where $Y_{\mathrm{ij}}$ is the data of cyanide-utilizing bacteria, $\mu$ is the over-all mean, $A_{\mathrm{i}}$ is the cyanide levels effect $(\mathrm{i}=1-4)$, and $\varepsilon_{\mathrm{ij}}$ is the residue. Duncan's multiples ranging test was run to check the statistical differences of treatment means at $p<0.05$.

Data from in vitro study were analyzed using the PROC GLM of SAS [26] according to a $5 \times 3$ factorial arrangement in a completely randomized system. The model is:

$$
Y_{\mathrm{ijk}}=\mu+a_{\mathrm{i}}+b_{\mathrm{j}}+a b_{\mathrm{ij}}+\varepsilon_{\mathrm{ijk}}
$$

Where $Y_{\mathrm{ijk}}$ are the response variance, $\mu$ is the over-all mean, $a_{\mathrm{i}}$ is the level of FCR at $0,260,350$, 440 , and $530 \mathrm{~g} / \mathrm{kg}$ of $0.5 \mathrm{~g} \mathrm{DM}(\mathrm{i}, 1-5), b_{\mathrm{j}}$ is the levels of PELFUR at 0,15 and $30 \mathrm{~g} / \mathrm{kg}$ of DM substrate $(\mathrm{j}, 1-3), a b_{\mathrm{ij}}$ is the interaction effect, and $\varepsilon_{\mathrm{ijk}}$ is the residue. The means of response variances were reported with standard error of mean. Duncan's multiples ranging test was run to check the statistical differences of treatment means at $\mathrm{p}<0.05$.

\section{Results and discussions}

\subsection{Screening of cyanide-utilizing bacteria from rumen}

Figure 1 shows the effect of cyanide concentration on the dynamic growth of cyanide-utilizing bacteria. Adding different doses of cyanide significantly affected cyanide-utilizing rumen bacterial growth $(\mathrm{p}<0.05)$. The population of cyanide-utilizing bacteria were $525 \times 10^{3}, 850 \times 10^{3}, 1000 \times 10^{3}$, and $100 \times 10^{3} \mathrm{cfu} / \mathrm{g}$ FM for media containing cyanide at $0,150,300$, and $450 \mathrm{ppm}$, respectively. Increasing the concentration of cyanide from 0 to 150 and 150 to $300 \mathrm{ppm}$, resulted in an increase in cyanide-utilizing rumen bacteria of $38.2 \%$ and $15.0 \%$, respectively. The results confirm hypothesis that the rumen fluid contains bacteria which break down cyanide for the use of cell synthesis. Subsequently, it could be assumed that cyanide is used by the bacteria as a nutrient for their growth, with cyanide acting as a nitrogen source. This finding is consistent with Razanamahandry et al. [27] study which showed that certain bacteria are capable of using cyanide as a nitrogen source through enzymes which catalyzed the conversion of the sulfur species to rhodanese and mercaptopyruvatesulfurtransferase. Nevertheless, increasing the concentration of cyanide from 300 to $450 \mathrm{ppm}$ 
decreased cyanide-utilizing rumen bacteria by $90 \%$. This could be due to the addition of cyanide up to $450 \mathrm{ppm}$ would result in high bacterial toxicity and thus inhibited cytochrome oxidase and interferes with some of the key biochemical reactions of activities (i.e., the reduction of oxygen in the cytochrome respiratory chain, the electron transport chain and the activity of enzymes such as catalase and oxidase) [28]. The present results demonstrate that bacteria could detoxify cyanide concentration not more than $450 \mathrm{ppm}$ in $0.5 \mathrm{~g}$ substrate and would be applied to feeding animals with diets containing cyanide at level lower than $450 \mathrm{ppm}$. This agrees with the findings of Kang and Kim [29], who studied the degradation of cyanide by a mixture of bacteria and demonstrated that cyanide played a role as a substrate up to $300 \mathrm{ppm}$, in which the mixture promoted the maximum growth rate of bacteria and the removal of cyanide. This is the first discovery of cyanide-utilizing bacteria in the rumen capable of degrading cyanide, and cyanide might function as a nitrogen source for bacterial cell synthesis. Furthermore, several reports demonstrate that the antinutritive substances can be detoxified by specific microbes contained in the rumen. Jones and Megarrity [7] stated that the infusion of ruminants with mixed bacterial culture introduced from Hawaiian goats could resolve the leucaena toxicity problem in northern Australia, as they contain Synergistes jonesii, capable of degrading mimosine, 3,4-dihydroxy pyridine (3,4 DHP), and 2,3 DHP. Similarly, Intanoo et al. [30] found that the isolated rumen yeast could detoxify aflatoxin contained in the diet of dairy cattle. Thus, the degradation of cyanide in the present in vitro study, indicated that rumen bacteria might solve the cyanide toxicity problem in ruminants when feedstuffs containing cyanide is fed. However, investigation of species of cyanide-utilizing bacteria in the rumen is essentially required for future studies.

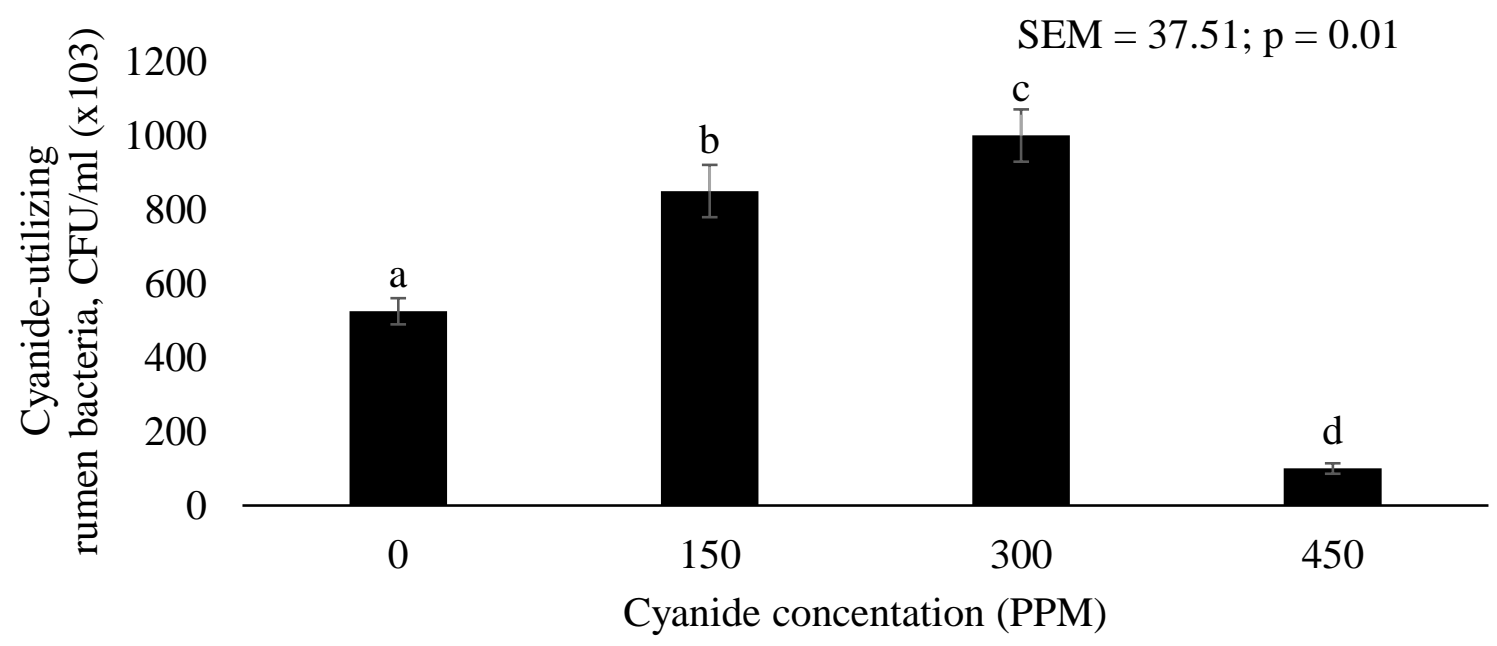

Figure 1. Cyanide-utilizing rumen bacteria growth curve at 0, 150, 300 and 450 ppm initial cyanide concentration.

\subsection{In vitro gas production study}

\subsubsection{Gas kinetics and cumulative gas production}

Figure 2 presents the cumulative gas production dynamics at various hours of incubation, and values of gas kinetics and cumulative gas production at $96 \mathrm{~h}$ are listed in Table 2. No interaction effects were found between FCR and PELFUR doses, in terms of gas production from immediately soluble fractions (a), gas production from insoluble fractions (b), gas production rate constants for the insoluble fractions $(\mathrm{c})$, potential extent of gas production $(\mathrm{a}+\mathrm{b})$, and cumulative gas production at $96 \mathrm{~h}$ of incubation ( $p>0.05$ ). However, increasing the FCR in the diet (0 to $530 \mathrm{~g} / \mathrm{kg}$ ) affected the gas production from immediately soluble fractions (a), gas production from insoluble fractions (b), and potential extent of gas production $(a+b)$ or cumulative gas production at $96 \mathrm{~h}$ of incubation $(\mathrm{p}<0.05)$. 
Increasing the FCR level to more than $260 \mathrm{~g} / \mathrm{kg}$ of DM substrate could increase cumulative gas production, whereas increasing the PELFUR from 0 to $30 \mathrm{~g} / \mathrm{kg}$ affected the gas production from the insoluble fractions $(b)$, potential extent of gas production $(a+b)$, and cumulative gas production at 96 $\mathrm{h}$ of incubation $(\mathrm{p}<0.05)$ but had no effect on gas production from immediately soluble fractions (a) $(\mathrm{p}>0.05)$. These results demonstrate that increasing doses of PELFUR from 15 to $30 \mathrm{~g} / \mathrm{kg}$ increased the cumulative gas production when compared with that of $0 \mathrm{~g}$ PELFUR $/ \mathrm{kg}$. This might be due to the increased number of microorganisms [4], which could improve feed degradability and to enhance the performance of cumulative gas production. Furthermore, FCR is filled with starch; thus, carbohydrates are shifted from cassava to starch, attributing to higher nutrients availability and resulting in effective cumulative gas production [3].

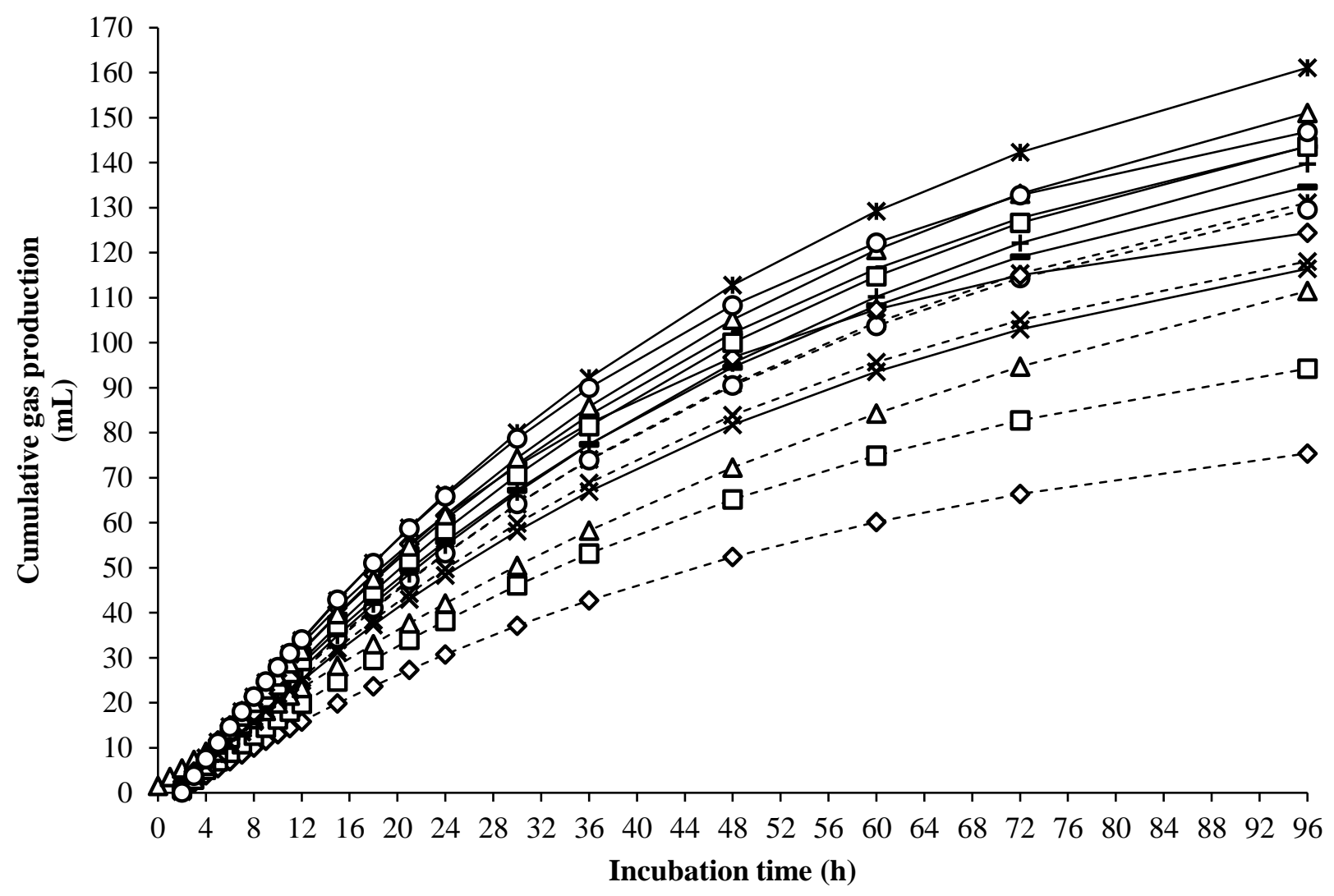

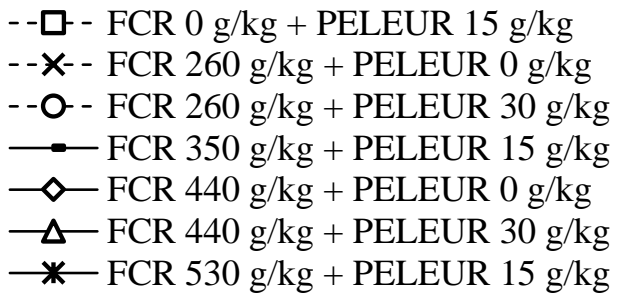

- - - - FCR $0 \mathrm{~g} / \mathrm{kg}+$ PELEUR $15 \mathrm{~g} / \mathrm{kg}$

- - - - FCR $260 \mathrm{~g} / \mathrm{kg}+$ PELEUR $0 \mathrm{~g} / \mathrm{kg}$

- - - - FCR $260 \mathrm{~g} / \mathrm{kg}$ + PELEUR $30 \mathrm{~g} / \mathrm{kg}$

$\checkmark-$ FCR $440 \mathrm{~g} / \mathrm{kg}+$ PELEUR $0 \mathrm{~g} / \mathrm{kg}$

*

Figure 2. Effect of fresh cassava root (FCR) with pellet containing high sulfur (PELFUR) on cumulative gas during incubation times. 
Table 2. Effect of fresh cassava root (FCR) with pellet containing high sulfur (PELFUR) on gas kinetics and cumulative gas at $96 \mathrm{~h}$ after incubation.

\begin{tabular}{|c|c|c|c|c|c|c|c|}
\hline \multirow[t]{2}{*}{ Item } & \multirow{2}{*}{$\begin{array}{c}\text { FCR } \\
(\mathrm{g} / \mathrm{kg})\end{array}$} & \multirow{2}{*}{$\begin{array}{c}\text { PELFUR } \\
\text { (g/kg) }\end{array}$} & \multicolumn{4}{|c|}{ Gas kinetics } & \multirow{2}{*}{$\begin{array}{c}\text { Cumulative } \\
\text { gas } \\
(\mathrm{ml})\end{array}$} \\
\hline & & & $\mathbf{a}$ & $\mathbf{b}$ & c & $\mathbf{a}+\mathbf{b}$ & \\
\hline & 0 & 0 & -2.79 & 94.60 & 0.02 & 91.81 & 75.43 \\
\hline & 0 & 15 & -3.08 & 118.87 & 0.02 & 115.78 & 94.16 \\
\hline & 0 & 30 & 1.56 & 158.86 & 0.02 & 160.42 & 111.40 \\
\hline & 260 & 0 & -5.30 & 144.64 & 0.02 & 139.34 & 114.82 \\
\hline & 260 & 15 & -5.61 & 165.38 & 0.02 & 159.77 & 131.04 \\
\hline & 260 & 30 & -4.92 & 161.67 & 0.02 & 156.75 & 129.49 \\
\hline & 350 & 0 & -6.45 & 180.13 & 0.02 & 173.68 & 139.68 \\
\hline & 350 & 15 & -5.83 & 175.33 & 0.02 & 169.49 & 142.94 \\
\hline & 350 & 30 & -5.42 & 166.86 & 0.02 & 161.44 & 133.71 \\
\hline & 440 & 0 & -6.44 & 140.92 & 0.03 & 134.49 & 124.40 \\
\hline & 440 & 15 & -6.95 & 180.61 & 0.02 & 173.66 & 143.45 \\
\hline & 440 & 30 & -5.91 & 189.39 & 0.02 & 183.48 & 150.62 \\
\hline & 530 & 0 & -4.45 & 144.21 & 0.02 & 139.76 & 116.05 \\
\hline & 530 & 15 & -6.84 & 200.59 & 0.02 & 193.74 & 161.09 \\
\hline & 530 & 30 & -7.73 & 173.82 & 0.02 & 166.09 & 146.27 \\
\hline SEM & & & 0.95 & 13.52 & 0.01 & 13.07 & 9.08 \\
\hline \multicolumn{8}{|l|}{ Main effects } \\
\hline \multirow{5}{*}{$\begin{array}{l}\text { FCR } \\
(\mathrm{g} / \mathrm{kg})\end{array}$} & 0 & & $-1.44^{\mathrm{a}}$ & $124.11^{\mathrm{a}}$ & 0.02 & $122.67^{\mathrm{a}}$ & $93.66^{\mathrm{a}}$ \\
\hline & 260 & & $-5.28^{b}$ & $157.23^{\mathrm{b}}$ & 0.02 & $151.95^{\mathrm{b}}$ & $125.12^{\mathrm{b}}$ \\
\hline & 350 & & $-5.90^{\mathrm{b}}$ & $174.11^{\mathrm{b}}$ & 0.02 & $168.21^{\mathrm{b}}$ & $138.78^{\mathrm{bc}}$ \\
\hline & 440 & & $-6.43^{b}$ & $170.31^{\mathrm{b}}$ & 0.02 & $163.88^{b}$ & $139.49^{\mathrm{bc}}$ \\
\hline & 530 & & $-6.34^{b}$ & $172.87^{\mathrm{b}}$ & 0.02 & $166.53^{\mathrm{b}}$ & $141.14^{\mathrm{c}}$ \\
\hline \multirow{3}{*}{$\begin{array}{c}\text { PELFUR } \\
(\mathrm{g} / \mathrm{kg})\end{array}$} & 0 & & -5.08 & $140.90^{\mathrm{a}}$ & 0.02 & $135.82^{\mathrm{a}}$ & $114.07^{\mathrm{a}}$ \\
\hline & 15 & & -5.66 & $168.15^{\mathrm{b}}$ & 0.02 & $162.49^{\mathrm{b}}$ & $134.53^{\mathrm{b}}$ \\
\hline & 30 & & -4.48 & $170.12^{\mathrm{b}}$ & 0.02 & $165.64^{b}$ & $134.30^{\mathrm{b}}$ \\
\hline \multicolumn{8}{|c|}{ Significance of main effect and interaction } \\
\hline FCR & & & 0.01 & 0.01 & 0.64 & 0.01 & 0.01 \\
\hline PELFUR & & & 0.18 & 0.01 & 0.82 & 0.01 & 0.01 \\
\hline $\mathrm{FCR} \times \mathrm{PEL}$ & & & 0.07 & 0.15 & 0.99 & 0.10 & 0.29 \\
\hline
\end{tabular}

${ }^{a-b}$ Mean values in the same column with different superscripts are statistically different $(p<0.05), F C R=$ fresh cassava root, PELFUR = pellet containing high sulfur, SEM=standard error of the mean, $\mathrm{a}=$ the gas production from the immediately soluble fraction, $\mathrm{b}=$ the gas production from the insoluble fraction, $\mathrm{c}=$ the gas production rate constant from the insoluble fraction, $(\mathrm{a}+\mathrm{b})=$ the gas potential extent of gas production.

\subsubsection{In vitro fermentation and ruminal microbial population}

Table 3 presents the effect of FCR supplementation with PELFUR on in vitro rumen fermentation and ruminal microbial population using an in vitro gas development test. There was no interaction between FCR and PELFUR levels on all the parameters ( $p>0.05)$. Increasing doses of FCR supplementation decreased ruminal $\mathrm{pH}$. This could be due to an increase in FCR containing fermentable carbohydrate, which is rapidly fermented, resulting in decreased $\mathrm{pH}$. The $\mathrm{pH}$ continued dropping, averaging 6.90-6.86, possibly due to the bioconversion of available carbohydrates. However, ruminal $\mathrm{pH}$ for FCR and PELFUR was within the appropriate range for microbial synthesis and feed fermentation activity in rumen microbial enzyme degradation and feed fermentation activity in rumen [31]. 
Concentrations of $\mathrm{NH}_{3}-\mathrm{N}$ were significantly impacted $(\mathrm{p}<0.05)$ and decreased with increased rates of FCR supplementation. This could be due to a sufficient supply of energy from a rapidly fermentable source of carbohydrates to allow the efficient incorporation of peptides, free amino acids, and $\mathrm{NH}_{3}-\mathrm{N}$ into microbial cells [10]. Likewise, Cherdthong et al. [2] found that the concentration of $\mathrm{NH}_{3}-\mathrm{N}$ in the rumen increased with an increasing amount of FCR supplementation. Increasing the amount of PELFUR by 15 and $30 \mathrm{~g} / \mathrm{kg}$ also reduced the concentration of $\mathrm{NH}_{3}-\mathrm{N}$ by 2.44 and 2.42 $\mathrm{mg} / \mathrm{dL}$ compared to the control PELFUR group. This might be due to ruminal microorganisms that use $\mathrm{NH}_{3}-\mathrm{N}$ as a non-protein nitrogen source substrate for cell synthesis. Thus, microbial protein synthesis might require to use $\mathrm{NH}_{3}-\mathrm{N}$ with sulfide [3]. This result is consistent with what Supapong et al. [10] found that ruminal $\mathrm{NH}_{3}-\mathrm{N}$ concentrations was slightly lower $(15.20 \mathrm{mg} / \mathrm{dL})$, and complemented well with sulfur at $20 \mathrm{~g} / \mathrm{kg}$. Additionally, the FCR supplementation and PELFUR did not affect the protozoal and bacterial populations ( $p>0.05$ ), ranging $5.00 \times 10^{6}$ to $9.00 \times 10^{6}$ cells $/ \mathrm{ml}$ and $9.50 \times 10^{8}$ to $13.00 \times 10^{8}$ cells $/ \mathrm{ml}$, respectively.

The cyanide concentration in rumen fluid, as affected by PELFUR supplementation with FCR, is presented in Table 3. The results showed that cyanide concentration in rumen fluid decreased with PELFUR $(\mathrm{p}<0.05)$ supplementation. The doses of 15 and $30 \mathrm{~g}$ PELFUR/kg decreased the concentration of cyanide by $30.35-36.96 \%$ and $37.06-40.08 \%$, as compared to the control. The reduction of cyanide in the substrate could be due to the influence of the addition of sulfur. The availability of sulfur plays an important role in the degradation mechanism of microorganisms. Rhodanese can extract cyanide from cyanide-utilizing rumen bacteria. Sulfur transferase, rhodanese, reduces thiocyanate toxicity via lowering the content of cyanide and thiosulphate. Supapong et al. [10] indicated that the theoretical need for $1.2 \mathrm{~g}$ of sulfur to transfer to thiocyanate is to replace $1 \mathrm{~g}$ of cyanide. This is in line with the study of Cherdthong et al. [2], which revealed that the addition of 20 $\mathrm{g}$ sulfur $/ \mathrm{kg}$ and $40 \mathrm{~g}$ sulfur $/ \mathrm{kg}$ in the feed block to beef cattle receiving FCR can ensure sufficient cyanide reduction and conversion of thiocyanate. Furthermore, the above experiment of the screening of cyanide-utilizing rumen bacteria confirmed that increasing the dose of cyanide from FCR might stimulate these bacteria to detoxify cyanide. Therefore, providing sufficient substrates for cell synthesis of cyanide-utilizing rumen bacteria such as energy, amino acid and nitrogen sources could enhance bacterial growth and reduce cyanide concentration. 
Table 3. Effect of fresh cassava root (FCR) with pellet containing high sulfur (PELFUR) on ruminal $\mathrm{pH}$, the ammonia-nitrogen $\left(\mathrm{NH}_{3}-\mathrm{N}\right)$ concentration, ruminal microbial population and cyanide concentration.

\begin{tabular}{|c|c|c|c|c|c|c|c|}
\hline Item & $\begin{array}{l}\text { FCR } \\
(\mathrm{g} / \mathrm{kg})\end{array}$ & $\begin{array}{c}\text { PELFUR } \\
\text { (g/kg) }\end{array}$ & pH & $\begin{array}{c}\mathrm{NH}_{3}-\mathrm{N} \\
(\mathrm{mg} / \mathrm{dL})\end{array}$ & $\begin{array}{c}\text { Protozoa } \\
\left(\times 10^{6} \text { cell } / \mathrm{ml}\right)\end{array}$ & $\begin{array}{c}\text { Bacteria } \\
\left(\times 10^{8} \text { cell } / \mathrm{ml}\right)\end{array}$ & $\begin{array}{r}\text { Cyanide } \\
(\text { ppm) }\end{array}$ \\
\hline & 0 & 0 & 6.91 & 16.86 & 7.00 & 9.50 & $0.00^{\mathrm{a}}$ \\
\hline & 0 & 15 & 6.89 & 14.96 & 6.00 & 11.00 & $0.00^{\mathrm{a}}$ \\
\hline & 0 & 30 & 6.90 & 15.21 & 6.00 & 11.50 & $0.00^{\mathrm{a}}$ \\
\hline & 260 & 0 & 6.89 & 15.71 & 6.00 & 10.50 & $0.26^{\mathrm{f}}$ \\
\hline & 260 & 15 & 6.86 & 11.51 & 6.00 & 11.50 & $0.18^{\mathrm{c}}$ \\
\hline & 260 & 30 & 6.87 & 12.91 & 5.00 & 12.00 & $0.15^{\mathrm{b}}$ \\
\hline & 350 & 0 & 6.87 & 14.31 & 7.00 & 11.00 & $0.34^{\mathrm{k}}$ \\
\hline & 350 & 15 & 6.86 & 12.21 & 7.00 & 12.00 & $0.24^{\mathrm{e}}$ \\
\hline & 350 & 30 & 6.85 & 12.21 & 7.00 & 12.50 & $0.21^{\mathrm{d}}$ \\
\hline & 440 & 0 & 6.85 & 15.71 & 6.00 & 11.50 & $0.43^{1}$ \\
\hline & 440 & 15 & 6.83 & 12.96 & 9.00 & 12.50 & $0.29^{\mathrm{h}}$ \\
\hline & 440 & 30 & 6.83 & 12.41 & 8.00 & 12.50 & $0.27^{\mathrm{g}}$ \\
\hline & 530 & 0 & 6.82 & 17.26 & 8.50 & 12.00 & $0.51^{\mathrm{m}}$ \\
\hline & 530 & 15 & 6.83 & 16.01 & 8.00 & 13.00 & $0.32^{\mathrm{j}}$ \\
\hline & 530 & 30 & 6.83 & 15.01 & 9.00 & 13.00 & $0.31^{\mathrm{i}}$ \\
\hline SEM & & & 0.01 & 0.53 & 1.85 & 0.73 & 0.003 \\
\hline \multicolumn{8}{|l|}{ Main effects } \\
\hline \multirow{5}{*}{$\begin{array}{c}\text { FCR } \\
(\mathrm{g} / \mathrm{kg})\end{array}$} & 0 & & $6.90^{\mathrm{a}}$ & $15.68^{\mathrm{a}}$ & 6.30 & 10.70 & $0.00^{\mathrm{a}}$ \\
\hline & 260 & & $6.87^{b}$ & $13.38^{\mathrm{b}}$ & 5.70 & 11.30 & $0.20^{\mathrm{b}}$ \\
\hline & 350 & & $6.86^{\mathrm{c}}$ & $12.91^{\mathrm{b}}$ & 7.00 & 11.80 & $0.26^{\mathrm{c}}$ \\
\hline & 440 & & $6.84^{\mathrm{d}}$ & $13.69^{\mathrm{b}}$ & 7.70 & 12.20 & $0.33^{\mathrm{d}}$ \\
\hline & 530 & & $6.83^{\mathrm{d}}$ & $16.09^{\mathrm{a}}$ & 8.50 & 12.70 & $0.38^{\mathrm{e}}$ \\
\hline \multirow{3}{*}{$\begin{array}{l}\text { PELFUR } \\
(\mathrm{g} / \mathrm{kg})\end{array}$} & 0 & & $6.87^{\mathrm{a}}$ & $15.97^{\mathrm{a}}$ & 6.90 & 10.90 & $0.31^{\mathrm{a}}$ \\
\hline & 15 & & $6.85^{\mathrm{b}}$ & $13.53^{\mathrm{b}}$ & 7.20 & 12.00 & $0.21^{\mathrm{b}}$ \\
\hline & 30 & & $6.86^{\mathrm{b}}$ & $13.55^{\mathrm{b}}$ & 7.00 & 12.30 & $0.19^{c}$ \\
\hline \multicolumn{8}{|c|}{ Significance of main effect and interaction } \\
\hline FCR & & & 0.01 & 0.01 & 0.40 & 0.22 & 0.01 \\
\hline PELFUR & & & 0.04 & 0.01 & 0.97 & 0.65 & 0.01 \\
\hline FCR $x$ PELFUR & & & 0.28 & 0.23 & 0.98 & 0.90 & 0.01 \\
\hline
\end{tabular}

${ }^{a-d}$ Mean values in the same column with different superscripts are statistically different $(\mathrm{p}<0.05), \mathrm{FCR}$

$=$ fresh cassava root, PELFUR = pellet containing high sulfur, $\mathrm{SEM}=$ standard error of the mean .

\subsubsection{In vitro degradability}

Table 4 provides the results of in vitro degradability at different incubation periods. Effects of interaction between FCR and PELFUR on degradabilities were obtained $(p<0.05)$. Results showed that in vitro degradability of dry matter (IVDMD) and in vitro degradability of organic matter (IVOMD) following incubation increased at 12 and $24 \mathrm{~h}$, due to PELFUR supplementation with FCR and increased more $(651.7 \mathrm{~g} / \mathrm{kg} \mathrm{DM}$ and $672.1 \mathrm{~g} / \mathrm{kg} \mathrm{DM} ; 690.0 \mathrm{~g} / \mathrm{kg} \mathrm{DM}$ and $725.9 \mathrm{~g} / \mathrm{kg} \mathrm{DM}$, respectively) with $15 \mathrm{~g}$ PELFUR/kg $(\mathrm{p}<0.05)$ in $440 \mathrm{~g}$ FCR $/ \mathrm{kg}$. This is probably due to the high concentration of nonstructural carbohydrates in the FCR, which can easily be broken down in the rumen and increase the bacterial population by improving the degradabilities of DM and OM in vitro [3]. Sulfur is also an important part of the rumen bacteria. The ruminant relies on ruminant microbes to transform sulfate into hydrogen sulfite, which is used to produce essential amino acids (cysteine and methionine) for the synthesis of microbial ruminants [6]. Consequently, an adequate supply of 
sulfur would enhance the growth of microorganisms and enhance nutrient digestion. Similar findings were reported by Cherdthong et al. [2], who revealed that cattle fed $40 \mathrm{~g}$ sulfur $/ \mathrm{kg}$ had improved digestibility of DM and OM compared to those fed $20 \mathrm{~g}$ sulfur $/ \mathrm{kg}$ in the feed block with supplementation of FCR at 10 and $15 \mathrm{~g} / \mathrm{kg}$ of BW.

Table 4. The effect of fresh cassava root (FCR) with pellet containing high sulfur (PELFUR) on in vitro digestibility of nutrients.

\begin{tabular}{|c|c|c|c|c|c|c|c|c|}
\hline \multirow[t]{2}{*}{ Item } & \multirow[t]{2}{*}{$\begin{array}{l}\text { FCR } \\
(\mathrm{g} / \mathrm{kg})\end{array}$} & \multirow[t]{2}{*}{$\begin{array}{c}\text { PELFUR } \\
(\mathrm{g} / \mathrm{kg})\end{array}$} & \multicolumn{3}{|c|}{$\begin{array}{l}\text { IVDMD } \\
\qquad(\mathrm{g} / \mathrm{kg} \text { DM) }\end{array}$} & \multicolumn{3}{|c|}{$\begin{array}{l}\text { IVOMD } \\
\qquad(\mathrm{g} / \mathrm{kg} \mathrm{DM})\end{array}$} \\
\hline & & & $12 \mathrm{~h}$ & $24 \mathrm{~h}$ & Mean & $12 \mathrm{~h}$ & $24 \mathrm{~h}$ & Mean \\
\hline & 0 & 0 & $562.6^{\mathrm{a}}$ & $598.8^{\mathrm{a}}$ & $580.7^{\mathrm{a}}$ & $600.8^{\mathrm{a}}$ & $639.5^{\mathrm{a}}$ & $620.2^{\mathrm{a}}$ \\
\hline & 0 & 15 & $569.5^{\mathrm{a}}$ & $603.7^{\mathrm{ab}}$ & $586.6^{\mathrm{a}}$ & $612.7^{\mathrm{ab}}$ & $647.3^{\mathrm{ab}}$ & $630.0^{\mathrm{ab}}$ \\
\hline & 0 & 30 & $559.6^{\mathrm{a}}$ & $613.9^{\mathrm{bc}}$ & $586.7^{\mathrm{a}}$ & $601.6^{\mathrm{a}}$ & $652.2^{\mathrm{bc}}$ & $626.9^{\mathrm{ab}}$ \\
\hline & 260 & 0 & $582.9^{c}$ & $611.7^{\mathrm{abc}}$ & $597.3^{b}$ & $623.1^{\mathrm{bc}}$ & $652.6^{\mathrm{bc}}$ & $637.8^{b c}$ \\
\hline & 260 & 15 & $601.7^{\mathrm{dh}}$ & $621.7^{\mathrm{c}}$ & $611.7^{\mathrm{c}}$ & $644.6^{\mathrm{de}}$ & $663.5^{\mathrm{c}}$ & $654.1^{\mathrm{de}}$ \\
\hline & 260 & 30 & $597.2^{\mathrm{d}}$ & $637.2^{\mathrm{de}}$ & $617.2^{\mathrm{cd}}$ & $637.9^{d}$ & $679.0^{\mathrm{d}}$ & $658.5^{\mathrm{ef}}$ \\
\hline & 350 & 0 & $603.9^{\text {bdh }}$ & $616.2^{\mathrm{bc}}$ & $610.1^{\mathrm{c}}$ & $630.5^{\mathrm{cd}}$ & $663.1^{\mathrm{c}}$ & $646.8^{\mathrm{cd}}$ \\
\hline & 350 & 15 & $616.4^{\mathrm{e}}$ & $649.3^{\text {ef }}$ & $632.9^{\mathrm{e}}$ & $653.2^{\mathrm{e}}$ & $689.6^{\mathrm{de}}$ & $671.4^{\mathrm{g}}$ \\
\hline & 350 & 30 & $608.6^{\text {beh }}$ & $654.7^{\mathrm{fg}}$ & $631.7^{\mathrm{e}}$ & $644.0^{\mathrm{de}}$ & $693.2^{\mathrm{e}}$ & $668.6^{\mathrm{fg}}$ \\
\hline & 440 & 0 & $612.3^{\text {be }}$ & $635.7^{\mathrm{d}}$ & $624.0^{\mathrm{de}}$ & $637.8^{\mathrm{d}}$ & $681.2^{\mathrm{de}}$ & $659.5^{\mathrm{ef}}$ \\
\hline & 440 & 15 & $647.8^{\mathrm{g}}$ & $668.5^{\mathrm{h}}$ & $658.1^{\mathrm{gh}}$ & $684.3^{\mathrm{gh}}$ & $720.7^{\mathrm{fg}}$ & $702.5^{\mathrm{ij}}$ \\
\hline & 440 & 30 & $629.0^{\mathrm{f}}$ & $664.2^{\mathrm{gh}}$ & $646.6^{\mathrm{f}}$ & $668.4^{\mathrm{f}}$ & $713.0^{\mathrm{f}}$ & $690.7^{\mathrm{h}}$ \\
\hline & 530 & 0 & $617.5^{\mathrm{e}}$ & $643.5^{\text {def }}$ & $630.5^{\mathrm{e}}$ & $642.2^{\mathrm{de}}$ & $689.3^{\mathrm{de}}$ & $665.7^{\mathrm{fg}}$ \\
\hline & 530 & 15 & $651.7^{\mathrm{g}}$ & $672.1^{\mathrm{h}}$ & $661.9^{\mathrm{h}}$ & $690.0^{\mathrm{h}}$ & $725.9^{\mathrm{g}}$ & $708.0^{\mathrm{j}}$ \\
\hline & 530 & 30 & $633.7^{\mathrm{f}}$ & $665.9^{\mathrm{gh}}$ & $649.8^{\mathrm{fg}}$ & $672.4^{\mathrm{fg}}$ & $720.4^{\mathrm{fg}}$ & $696.4^{\mathrm{hi}}$ \\
\hline SEM & & & 3.4 & 4.3 & 3.1 & 4.9 & 4.1 & 3.7 \\
\hline \multicolumn{9}{|c|}{ Main effects } \\
\hline \multirow{5}{*}{$\begin{array}{c}\text { FCR } \\
(\mathrm{g} / \mathrm{kg})\end{array}$} & 0 & & $563.9^{\mathrm{a}}$ & $605.4^{\mathrm{a}}$ & $584.7^{\mathrm{a}}$ & $605.0^{\mathrm{a}}$ & $646.3^{a}$ & $625.7^{\mathrm{a}}$ \\
\hline & 260 & & $593.9^{\mathrm{b}}$ & $623.5^{\mathrm{b}}$ & $608.7^{\mathrm{b}}$ & $635.2^{\mathrm{b}}$ & $665.0^{\mathrm{b}}$ & $650.1^{\mathrm{b}}$ \\
\hline & 350 & & $609.6^{\mathrm{c}}$ & $640.1^{\mathrm{c}}$ & $624.9^{c}$ & $642.6^{\mathrm{c}}$ & $682.0^{c}$ & $662.3^{c}$ \\
\hline & 440 & & $629.7^{\mathrm{d}}$ & $656.1^{\mathrm{d}}$ & $642.9^{\mathrm{d}}$ & $663.5^{\mathrm{d}}$ & $705.0^{\mathrm{d}}$ & $684.2^{\mathrm{d}}$ \\
\hline & 530 & & $634.3^{\mathrm{d}}$ & $660.5^{\mathrm{d}}$ & $647.4^{\mathrm{d}}$ & $668.2^{\mathrm{d}}$ & $711.9^{\mathrm{d}}$ & $690.0^{\mathrm{d}}$ \\
\hline \multirow{3}{*}{$\begin{array}{c}\text { PELFUR } \\
(\mathrm{g} / \mathrm{kg})\end{array}$} & 0 & & $605.6^{\mathrm{a}}$ & $621.2^{\mathrm{a}}$ & $608.5^{\mathrm{a}}$ & $626.9^{\mathrm{a}}$ & $665.1^{\mathrm{a}}$ & $646.0^{\mathrm{a}}$ \\
\hline & 15 & & $617.4^{\mathrm{b}}$ & $643.0^{\mathrm{b}}$ & $630.2^{\mathrm{b}}$ & $657.0^{\mathrm{b}}$ & $689.4^{\mathrm{b}}$ & $673.2^{\mathrm{b}}$ \\
\hline & 30 & & $595.8^{\mathrm{c}}$ & $647.2^{\mathrm{b}}$ & $626.4^{\mathrm{b}}$ & $644.9^{c}$ & $691.6^{\mathrm{b}}$ & $668.2^{\mathrm{b}}$ \\
\hline \multicolumn{9}{|c|}{ Significance of main effect and interaction } \\
\hline FCR & & & 0.01 & 0.01 & 0.01 & 0.01 & 0.01 & 0.01 \\
\hline PELFUR & & & 0.01 & 0.01 & 0.01 & 0.01 & 0.01 & 0.01 \\
\hline $\mathrm{FCR} \times \mathrm{PEL}$ & & & 0.01 & 0.01 & 0.01 & 0.01 & 0.01 & 0.01 \\
\hline
\end{tabular}

${ }^{\text {a-h }}$ Mean values in the same column with different superscripts are statistically different $(\mathrm{p}<0.05), \mathrm{FCR}=$ fresh cassava root, PELFUR = pellet containing high sulfur, SEM=standard error of the mean, IVDMD = In vitro dry matter digestibility, IVOMD = In vitro organic matter digestibility

\subsubsection{Concentration of volatile fatty acids (VFAs)}

For total VFAs, VFA profiles, and ratio of $\mathrm{C} 2$ to $\mathrm{C} 3$, no interactions were found between FCR and PELFUR (Table 5; $\mathrm{p}>0.05$ ). However, the proportions of the total VFAs, C2, C3, and C4, as well as the ratio of $\mathrm{C} 2$ to $\mathrm{C} 3$ between supplementation with FCR $(\mathrm{p}<0.05)$ were significantly different. As the proportion of FCR increased to $530 \mathrm{~g} / \mathrm{kg}$ of DM the substrate, the volume of C3 increased by $14.6 \%$. The findings could be attributed to an increase in fermentable carbohydrate-containing FCR, which is rapidly fermented, thus resulting in high overall concentrations of VFA and C3 in rumen. 
Essentially, high C3 is beneficial for animals as the principal source of the synthesis of live glucose through gluconeogenesis. These findings are similar to those of Cherdthong et al. [2], which showed the high-FCR diet in Thai native cattle enhanced the C3 concentration, as compared with low FCR diets. Dagaew et al. [3] suggested that the change in the ratio of FCR to rice straw was 100: 0, with 20 and $40 \mathrm{~g}$ sulfur $/ \mathrm{kg}$ in the high sulfur feed block (FBS), enhancing the C3 ratio by $16.7 \%$ compared with the control group. Additionally, the sulfur concentration in PELFUR influenced the concentration of C3. When a high concentration of sulfur is added, the rise in the ruminal C3 concentration can imply that the $\mathrm{C} 3$ concentration can be used as a hydrogen sink when an excess of available ruminal sulfide is provided [10]. This is consistent with the findings of Promkot et al. [4], who revealed an increase in C 3 in fresh cassava foliage with $10 \mathrm{~g}$ sulfur $/ \mathrm{kg}$ supplementation, as sulfur was a precursor to microbial protein synthesis in rumen. Similarly, Supapong and Cherdthong [8] stated that supplementation of $20 \mathrm{~g}$ sulfur $/ \mathrm{kg}$ FTMR containing FCR, increased the propionic acid by $10.9 \%$, as compared with the non-supplementation with sulfur. 
Table 5. The effect of fresh cassava root (FCR) with pellet containing high sulfur (PELFUR) on volatile fatty acids (VFAs) concentrations.

\begin{tabular}{|c|c|c|c|c|c|c|c|}
\hline Item & $\begin{array}{c}\text { FCR } \\
(\mathrm{g} / \mathrm{kg})\end{array}$ & $\begin{array}{c}\text { PELFUR } \\
\text { (g/kg) }\end{array}$ & $(\mathrm{mmol} / \mathrm{l})$ & $\begin{array}{c}\text { Acetate } \\
\text { C2 }\end{array}$ & $\begin{array}{l}\text { Propionate } \\
\qquad \text { C3 } \\
(\mathrm{mol} / 100 \mathrm{~mol})\end{array}$ & $\begin{array}{c}\text { Butyrate } \\
\text { C4 }\end{array}$ & C2:C3 \\
\hline & 0 & 0 & 91.40 & 67.26 & 23.44 & 9.30 & 2.87 \\
\hline & 0 & 15 & 91.60 & 67.41 & 23.37 & 9.22 & 2.89 \\
\hline & 0 & 30 & 92.24 & 66.91 & 23.61 & 9.49 & 2.83 \\
\hline & 260 & 0 & 93.07 & 66.19 & 24.82 & 8.98 & 2.67 \\
\hline & 260 & 15 & 93.54 & 65.41 & 25.47 & 9.12 & 2.57 \\
\hline & 260 & 30 & 94.83 & 65.06 & 25.49 & 9.45 & 2.55 \\
\hline & 350 & 0 & 95.13 & 64.99 & 25.18 & 9.84 & 2.58 \\
\hline & 350 & 15 & 98.08 & 64.78 & 25.70 & 9.52 & 2.52 \\
\hline & 350 & 30 & 96.15 & 64.71 & 25.52 & 9.76 & 2.54 \\
\hline & 440 & 0 & 99.42 & 64.56 & 25.64 & 9.81 & 2.52 \\
\hline & 440 & 15 & 100.71 & 63.53 & 27.01 & 9.46 & 2.35 \\
\hline & 440 & 30 & 103.88 & 63.89 & 26.67 & 9.43 & 2.40 \\
\hline & 530 & 0 & 106.45 & 63.86 & 26.93 & 9.21 & 2.37 \\
\hline & 530 & 15 & 108.82 & 63.48 & 28.27 & 8.25 & 2.25 \\
\hline & 530 & 30 & 107.35 & 64.16 & 27.32 & 8.52 & 2.35 \\
\hline SEM & & & 2.53 & 0.33 & 0.34 & 0.32 & 0.04 \\
\hline \multicolumn{8}{|l|}{ Main effects } \\
\hline \multirow{5}{*}{$\begin{array}{c}\text { FCR } \\
(\mathrm{g} / \mathrm{kg})\end{array}$} & 0 & & $91.75^{\mathrm{a}}$ & $67.19^{\mathrm{a}}$ & $23.47^{\mathrm{a}}$ & $9.33^{\mathrm{b}}$ & $2.86^{\mathrm{a}}$ \\
\hline & 260 & & $93.81^{\mathrm{ab}}$ & $65.55^{\mathrm{b}}$ & $25.26^{\mathrm{b}}$ & $9.18^{\mathrm{ab}}$ & $2.60^{\mathrm{b}}$ \\
\hline & 350 & & $96.45^{\mathrm{b}}$ & $64.83^{c}$ & $25.47^{\mathrm{b}}$ & $9.71^{\mathrm{b}}$ & $2.55^{\mathrm{b}}$ \\
\hline & 440 & & $101.34^{\mathrm{c}}$ & $63.99^{\mathrm{d}}$ & $26.44^{\mathrm{c}}$ & $9.57^{\mathrm{b}}$ & $2.42^{\mathrm{c}}$ \\
\hline & 530 & & $107.54^{\mathrm{d}}$ & $63.83^{\mathrm{d}}$ & $27.51^{\mathrm{d}}$ & $8.66^{\mathrm{a}}$ & $2.32^{\mathrm{d}}$ \\
\hline \multirow{3}{*}{$\begin{array}{c}\text { PELFUR } \\
(\mathrm{g} / \mathrm{kg})\end{array}$} & 0 & & 97.09 & 65.37 & $25.20^{\mathrm{a}}$ & 9.43 & $2.60^{\mathrm{a}}$ \\
\hline & 15 & & 98.55 & 64.92 & $25.97^{\mathrm{b}}$ & 9.11 & $2.51^{\mathrm{b}}$ \\
\hline & 30 & & 98.89 & 64.95 & $25.72^{b}$ & 9.33 & $2.53^{\mathrm{b}}$ \\
\hline \multicolumn{8}{|c|}{ Significance of main effect and interaction } \\
\hline FCR & & & 0.01 & 0.01 & 0.01 & 0.01 & 0.01 \\
\hline PELFUR & & & 0.51 & 0.09 & 0.01 & 0.32 & 0.01 \\
\hline FCR*PELFUR & & & 0.98 & 0.41 & 0.48 & 0.74 & 0.45 \\
\hline
\end{tabular}

${ }^{\mathrm{a}-\mathrm{d}}$ Mean values in the same column with different superscripts are statistically different $(\mathrm{p}<0.05), \mathrm{FCR}=$ fresh cassava root,

PELFUR = pellet containing high sulfur, SEM=standard error of the mean

\section{Conclusions}

The cyanide-utilizing bacteria in the rumen were the first to be found, capable of degrading cyanide and withstanding cyanide by $300 \mathrm{ppm}$ in the media. However, the population decreased when a concentration of more than $450 \mathrm{ppm}$ was employed. It could be concluded that the inclusion of FCR in $530 \mathrm{~g} / \mathrm{kg}$ of DM substrate with $30 \mathrm{~g}$ PELFUR/ $\mathrm{kg}$ could increase the cumulative gas production, the bacterial populations, the in vitro degradability, the proportion of propionic acid, and the rate of the disappearance of cyanide without having any adverse effect on in vitro fermentation. Nevertheless, in vivo studies are required to investigate the effects of FCR and PELFUR in the practical feeding regimes. 
Author Contributions: Conceptualization, R.P. and A.C.; Formal analysis, R.P. and A.C.; Investigation, R.P.; Methodology, R.P. and A.C.; Writing original draft, R.P.; Writing review and editing, R.P., A.C. and M.W.

Funding: Animal Feed Inter Trade Co., Ltd, Thailand Research Fund (TRF) through the Researcher for Industry (RRi) program (contract grant PHD60I0080) and the Increase Production Efficiency and Meat Quality of Native Beef and Buffalo Research Group, Khon Kaen University (KKU).

Acknowledgments: We would like to thanks to the Tropical Feed Resources Research and Development Center (TROFREC), Department of Animal Science, Faculty of Agriculture, KKU for providing the research facilities.

Conflicts of Interest: The authors declare that they have no conflict of interest.

\section{References}

1. Wanapat, M.; Khampa, S. Effect of levels of supplementation of concentrate containing high levels of cassava chip on rumen ecology, microbial $\mathrm{N}$ supply and digestibility of nutrients in beef cattle. AsianAustralas. J. Anim. Sci. 2007, 20, 75-81.

2. Cherdthong, A.; Khonkhaeng, B.; Seankamsorn, A.; Supapong, C.; Wanapat, M.; Gunun, N.; Gunun, P.; Chanjula, P.; Polyorach, S. Effects of feeding fresh cassava root with high-sulfur feed block on feed utilization, rumen fermentation and blood metabolites in Thai native cattle. Trop. Anim. Health. Prod. 2018, 50, 1365-1371.

3. Dagaew, G.; Cherdthong, A.; Wanapat, M.; Chanjula, P. In vitro rumen gas production kinetics, hydrocyanic acid concentration and fermentation characteristics of fresh cassava root and feed block sulfur concentration. Anim. Prod. Sci. 2020, 60, 659-664.

4. Promkot, C.; Wanapat, M.; Wachirapakorn, C.; Navanukraw, C. Influence of sulphur on fresh cassava foliage and cassava hay incubate in rumen fluid of beef cattle. Asian-Australas. J. Anim. Sci. 2007, 20, 14241432 .

5. Aminlari, M. Distribution of the cyanide metabolizing enzyme rhodanese in different tissues of domestic animals. J. Vet. Pharmacol. Ther. 2006, 29, 128.

6. Promkot, C.; Wanapat, M. Effect of elemental sulfur supplementation on rumen environment parameters and utilization efficiency of fresh cassava foliage and cassava hay in dairy cattle. Asian-Australas. J. Anim. Sci. 2009, 22, 1366-1376.

7. Jones, R.J.; Megarrity, R.G. Successful transfer of DHP-degrading bacteria from Hawaiian goats to Australian ruminants to overcome the toxicity of Leucaena. Aust. Vet. J. 1986, 63, 259-262.

8. Supapong, C.; Cherdthong, A. Effect of sulfur concentrations in fermented total mixed rations containing fresh cassava root on rumen fermentation. Anim. Prod. Sci. 2020, 60, 1429-1434.

9. Tele, F.F. Chronic poisoning by hydrogen cyanide in cassava and its prevention in Africa and Latin America. Food. Nutr. Bull. 2002, 23, 407-412.

10. Supapong, C.; Cherdthong, A.; Wanapat, M.; Chanjula, P.; Uriyapongson, S. Effects of sulfur levels in fermented total mixed ration containing fresh cassava root on feed utilization, rumen characteristics, microbial protein synthesis, and blood metabolites in Thai native beef cattle. Animals. 2019, 9, 261.

11. Südekum, K.H.; Schröder, A.; Fiebelkorn, S.; Schwer, R.; Thalmann, A. Quality characteristics of pelleted compound feeds under varying storage conditions as influenced by purity and concentration of glycerol from biodiesel production. J. Anim. Feed Sci. 2008, 17, 120-136.

12. Seankamsorn, A.; Cherdthong, A.; Wanapat, M.; Supapong, C.; Khonkhaeng, B.; Uriyapongson, S.; Gunun, N.; Gunun, P.; Chanjula, P. Effect of dried rumen digesta pellet levels on feed use, rumen ecology, and blood metabolite in swamp buffalo. Trop. Anim. Health Prod. 2017, 48, 79-86.

13. Cherdthong, A.; Prachumchai, R.; Wanapat, M. In vitro evaluations of pellets containing Delonix regia seed meal for ruminants. Trop. Anim. Health Prod. 2019, 51, 2003-2010.

14. Kandasamy, S.; Dananjeyan, B.; Krishnamurthy, K.; Benckise, G. Aerobic cyanide degradation by bacterial isolates from cassava factory wastewater. Braz. J. Microbiol. 2015, 3, 659-666.

15. Moradkhani, M.; Yaghmaei, S.; Ghobadi Nejad, Z. Biodegradation of cyanide under alkaline conditions by a strain of pseudomonas putida isolated from gold mine soil and optimization of process variables through response surface methodology (RSM). Period. Polytech. Chem. 2018, 62, 265-273.

16. Kozaki, M.; Uchimura, T.; Okada, S. Experimental Manual for Lactic Acid Bacteria. Asakurasyoten, Tokyo, Japan. 1992.

17. AOAC., 16th edn. Official Methods of Analysis, vol. 2 AOAC, ed. Arlington, VA. 1998.

18. Van Soest, P.J.; Robertson, J.B.; Lewis, B.A. Methods for dietary fiber neutral detergent fiber, and non-starch polysaccharides in relation to animal nutrition. J. Dairy Sci. 1991, 74, 3583-3597. 
19. Bradbury, J.H.; Egan, S.M.; Lynch, M.J. Analysis of cyanide in cassava using acid hydrolysis of cyanogenic glucosides. J. Sci. Food. Agr. 1991, 55, 277-290.

20. Menke, K.H.; Steingass, H. Estimation of the energetic feed value obtained from chemical analysis and gas production using rumen fluid. Anim. Res. Dev. 1998, 28, 7-55.

21. Ørskov, E.R.; McDonald, I. The estimation of protein degradability in the rumen from incubation measurements weighted according to rate of passage. J. Agric. Sci. 1979, 92, 499-503.

22. Samuel, M.; Sagathewan, S.; Thomas, J.; Mathen, G. An HPLC method for estimation of volatile fatty acids of ruminal fluid. Indian J. Anim. Sci. 1997, 67, 805-811.

23. Galyean, M. Laboratory procedure in animal nutrition research. Department of Animal and Range Sciences, New Mexico State University: Las Cruces, NM, USA. 1989.

24. Lambert, J.L.; Ramasamy, J.; Paukstelis, J.F. Stable reagents for the colorimetric determination of cyanide by modified Konig reactions. Anal. Chem. 1975, 47, 916-918.

25. Tilley, J.M.A.; Terry, R.A. A two-stage technique for the digestion of forage crops. J. Br. Grassland Soc. 1963, 18, 104-111.

26. Statistical Analysis Systems. SAS/STAT Uuser's guide: version 6.12. 4th ed. SAS Inc., Cary, NC. 1996.

27. Razanamahandry, L.C.; Karoui, H.; Andrianisa, H.A.; Yacouba, H. Bioremediation of soil and water polluted by cyanide: A review. Afr. J. Environ. Sci. Technol. 2017, 11, 272-291.

28. McMahon, J.M.; White, W.L.B.; Sayre, R.T. Cyanogenesis in cassava (Manihot esculanta Crantz). J. Exp. Bot. 1995, 46, 731-741.

29. Kang, S.M.; Kim, D.J. Degradation of cyanide by a bacterial mixture composed of new types of cyanidedegrading bacteria. Biotechnol. Lett. 1993, 15, 201-206.

30. Intanoo, M.; Kongkeitkajorn, M.B.; Pattarajinda, V.; Bernard, J.K.; Callaway, T.R.; Suriyasathaporn, W.; Phasuk, Y. Isolation and screening of aflatoxin-detoxifying yeast and bacteria from ruminal fluids to reduce aflatoxin B1contamination in dairy cattle feed. J. Appl. Microbiol. 2018, 125, 1603-1613.

31. Cherdthong, A.; Prachumchai, R.; Wanapat, M.; Foiklang, S.; Chanjula, P. Effects of supplementation with royal poinciana seed meal (Delonix regia) on ruminal fermentation pattern, microbial protein synthesis, blood metabolites and mitigation of methane emissions in native Thai beef cattle. Animals. 2019, 9, 625. 